Hegedüs Hanga - dR. HORVÁth PÉTER LÁSZló RADICS MÁRTA

\title{
Értelmileg akadályozott, 1-8. osztályos általános iskolai tanulók receptív nyelvi képes- ségeinek vizsgálata a TROG-H teszt segítségével
}

\begin{abstract}
Az értelmileg akadályozott tanulók társadalmi életben való aktív részvételének egyik feltétele a jó kommunikációs képesség. Ennek megfelelöen a gyógypedagógiai nevelés-oktatás és fejlesztés központi dokumentumai (irányelvek, kerettantervek) kiemelt hangsúlyt helyeznek a célcsoport nyelvi kompetenciájának fejlesztésére. Másfelöl a fogyatékosság értelmezésének társadalmi modellje alapján a kommunikációs helyzetben a figyelmünk fókuszába kerül a befogadó (értelmileg akadályozott személy) mellett a közlő (esetünkben a gyógypedagógus) is. Elvárássá vált, hogy a közlö az üzenetét a könnyen érthető kommunikáció írott szabályrendszere alapján a befogadó nyelvi kompetenciájához illessze. Ugyanakkor nagyon kevés hazai kutatási eredményen alapuló tudással rendelkezünk úgy az értelmileg akadályozott tanulók nyelvi kompetenciájának jellemzőiröl, mint a könnyen érthető üzenet készítésére vonatkozó szabályrendszer szabályainak indokoltságáról.

A fentiek alapján úgy döntöttünk, hogy kutatást végzünk értelmileg akadályozott, 1-8. osztályos általános iskolai tanulók körében. A nyelvtani szerkezetek értését a TROG-H teszttel mértük fel két budapesti, egy kecskeméti és egy kiskőrösi köznevelési intézményben. Az alapsokaságot alkotó 129 föből 77 értelmileg akadályozott tanulót sikerült a kutatásba bevonni. Ebben a tanulmányban csak részeredményeket közlünk. A TROG-H teszt négy, a tagadó szerkezetek értésére irányuló blokkjának felvétele során nyert adatok elemzése alapján megállapítottuk, hogy a tagadó szerkezetek megértése komoly kihívás elé állítja az értelmileg akadályozott tanulókat. Ennek megfelelöen javaslatot teszünk a tagadó szerkezetek tanításának módszerére, illetve a könnyen érthetö üzenet készítésének új szabályaira.

A Szegedi Tudományegyetem Juhász Gyula Pedagógusképző Karán 2020. szeptember 1-je és 2021. június 30-a között futó kutatási programot a magyar kormány az Új Nemzeti Kiválóság Program keretében támogatja.

Kulcsszavak: TROG-H teszt, nyelvtani szerkezetek megértése, értelmileg akadályozott tanulók beszédértése, tagadás, tagadó szerkezetek, könnyen érthetö kommunikáció, könnyen érthető üzenetek készitésének szabályai

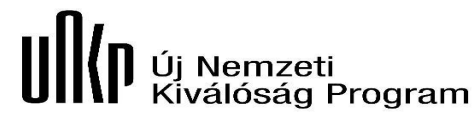

\section{BEVEZETÉS}

Az értelmileg akadályozott személyek társadalmi életben való aktív részvételének egyik feltétele a jó kommunikációs készség (Csákvári, 2006). Az előző kijelentést gyógypedagógusként olvasva figyelmünk fókuszába az értelmileg akadályozott tanulók nyelvi kompetenciájának fejlesztése kerül. És valóban: a gyógypedagógiai nevelés-oktatás tartalmát meghatározó központi dokumentumok (Irányelvek, 2020; kommunikáció kerettanterv 1-8. osztály; 2020; olvasás-írás kerettanterv 1-8. osztály, 2020) kiemelt hangsúlyt helyeznek erre a gyógypedagógusi feladatra. Az értelmileg akadályozott gyermek nyelvi kompetenciájáról szerzett tudományos ismereteknek kellene az iskolai fejlesztés, nevelés és oktatás alapjául szolgálniuk. Jelenleg 
azonban nagyon kevés magyarországi mérésen alapuló tudományos eredmény áll rendelkezésünkre (Radványi \& Pléh, 2002; Radványi, 2005; Lukács \& mtsai, 2008; Lukács \& mtsai, 2013; Lukács \& Kas, 2014).

Ennek ellenére fontos, hogy a kommunikációban részt vevő értelmileg akadályozott tanulókat felkészítsük arra, hogy magukat választékos szókinccsel, a magyar nyelv nyelvtani szabályainak tökéletesen megfelelő fogalmazásmóddal fejezzék ki. A sikeres kommunikációnak ez azonban nem a célja, hanem az eszköze. A mindennapi élet szempontjából a kommunikáció célja többek között például az, hogy szükségletünk kifejezésével a partnerünket adekvát cselekvésre bírjuk (Sápiné, 2020). Például rávegyük arra, hogy adjon nekünk egy pohár vizet. Ezt a célt elérhetjük választékos szókinccsel, grammatikailag helyesen és udvariasan megformált mondattal. Remélhetőleg hasonló eredményre jutunk akkor is, ha az üzenet lényegét kifejező szókinccsel, agrammatikusan csak annyit mondunk: „Kér víz”. És sikerrel járhatunk nonverbális (nem nyelvi) jelekkel is: a fejünkkel a vízcsap irányába biccentve, miközben a kezünkkel egy képzeletbeli poharat formázva ivó mozdulatot teszünk (Kocsisné \& mtsai, 2013).

Ugyanakkor a fogyatékosság szociális/társadalmi modellje alapján fel kell tennünk magunknak azt a kérdést is, hogy milyen környezeti tényezők akadályozzák az eredményes kommunikációt. Ebben a megközelítésben az értelmileg akadályozott emberek az információhoz való hozzáférés során azért ütköznek akadályokba, mert a többségi társadalom tagjai (esetünkben a közlök) az információt bonyolultan, nehezen értelmezhető módon fogalmazzák meg. A kommunikáció sikertelenségének oka nem (csak) az értelmileg akadályozott személy (befogadó) nyelvi kompetenciájának az átlagtól elmaradó szintjében keresendő, hanem a közlő kifejezőkészségében (Horváth, 2020a és 2020b).

Ezt ismerték fel a sajátos nevelési igényủ tanulók iskolai oktatásának irányelveit megfogalmazó szerzők is akkor, amikor a „középsúlyos értelmi fogyatékos tanulók iskolai nevelésének-oktatásának irányelvei” című fejezetben, a „Magyar nyelv és irodalom" tanulási területet érintő ajánlásokról szóló 5. 3. 1. alfejezetben, a célok és fejlesztési feladatok között a tanulási terület speciális feladatainál így fogalmaznak: „Szövegalkotáskor a könnyen érthető kommunikáció szabályaihoz kell igazodni" (Irányelvek, 2020:66). A könnyen érthető kommunikáció módszertanának szakemberek részére történő oktatása során a cél éppen az, hogy a közlő, esetünkben a gyógypedagógus megtanulja a gondolatainak a tudatos megformálását, éppen a befogadó nyelvi kompetenciájának szintjére figyelemmel. A könynyen érthető üzenet készítésekor az információt - írott szabályrendszer alapján (Inclusion Europe \& ÉFOÉSZ, 2009) - a befogadó számára érthető formába öntjük. A szabályrendszerben megfogalmazott szabályokat azonban magyarországi tudományos kutatási eredmények még nem támasztják alá (Hegedüs, 2020; Horváth, 2020c).

A fentiek alapján indokoltnak tủnt egy olyan kutatási program lebonyolítása, amelynek keretében kifejezetten az értelmileg akadályozott tanulók nyelvi kompetenciájára összpontosítunk. Reményeink szerint a kutatás eredményeit egyszerre tudjuk hasznosítani a célcsoport anyanyelvi nevelése módszertanának és a könynyen érthető üzenet készítése szabályrendszerének fejlesztésében.

A nyelvi kompetencia egy bonyolult, többrétegű fogalom. Valamennyi réteg feltárása és mérése meghaladja lehetőségeinket, és meghaladná jelen tanulmány terje- 
delmi kereteit is. Ezért ebben a tanulmányban a továbbiakban csak a tagadó szerkezetek kérdéskörével foglalkozunk; a téma szűkítését a szerzők szubjektív kutatói kíváncsisága magyarázza csupán.

\section{TAGADÓ SZERKEZET TANÍTÁSA AZ ÉRTEL- MILEG AKADÁLYOZOTT, 1-8. OSZTÁLYOS TANULÓK OKTATÁSÁHOZ KÉSZÍTETT KOM- MUNIKÁCIÓ ÉS OLVASÁS-ÍRÁS KERETTAN- TERVEK ALAPJÁN}

Az értelmileg akadályozott gyermek nyelvi fejlődését számos, egymással bonyolult kölcsönhatásba lépő belső és külső tényező formálja (Babarczy \& mtsai, 2015). Így van ez a tagadószó (például nem, sem) és tiltószó (ne, se), a tagadó jelentésủ általános főnévi (senki, semmi), melléknévi (például semmilyen, semekkora, sehány, sehol), határozószói [semmikor, soha, sehogy(an)] névmások és az egyszeres, kétszeres (például de nem; nemcsak... de; sem... sem) vagy többszörös tagadást kifejező nyelvtani szerkezetek jelentésének megértésével, ezen kifejezések alkalmazásával is (Keszler \& Lengyel, 2019). Nevezzük a fentieket együtt a továbbiakban tagadásnak.

Az egyik ilyen külső tényező a gyermek tudatos iskolai oktatása, nevelése és fejlesztése. A tagadás életkorhoz köthető tényleges tanítására vonatkozó magyar empirikus adatok és információk hiányában a tagadás tanításának megtervezését előíró dokumentumhoz tudunk csak nyúlni. A gyógypedagógus pedagógiai tervező munkáját a kerettantervek határozzák meg. Témánk szempontjából a „kommunikáció” és az „olvasás-írás” tantárgyak 1-8. osztályfokokra érvényes kerettantervei tekinthetők relevánsnak. Ezért a kerettanterveket egy nagyon egyszerü szempont szerint dokumentumelemzésnek vetettük alá: rákerestünk a „tagadó szerkezet”, a „tagadás” és a „nem” kifejezésekre. A kerettantervekben a „tagadó szerkezet” és a „tagadás” kifejezésekre egy találatot sem kaptunk. A „nem” kifejezésre keresve az olvasás-írás kerettantervben hat találatot kaptunk, de ebből egy sem volt releváns a tagadás tanításának szempontjából. A kommunikáció kerettantervben ötven találatot kaptunk a „nem” kifejezésre, amiböl tizenhárom bizonyult relevánsnak. Első, második évfolyamon a cselekvéshez kötődő „nem szabad”, „Nono!”, „nem” és a fejrázás, valamint a kívánságot kifejező „nem kérem” jelenik meg. Az „enyém” és „nem enyém” birtokos névmás tanításának a célja az enyém és a tiéd, övé elkülönítése. Harmadik és negyedik évfolyamon újra egy egyes szám első személyű, cselekvést kifejező „nem tudom megtenni”, és a viszonyulásra utaló „szeretem” - „nem szeretem”, az „ehető” - „nem ehető” kifejezéspár jelenik meg elsajátítandó fogalomként. Ötödik és hatodik évfolyamon a vásárlás témakörében, csoportosítási céllal jelenik meg a „fontos” - „nem fontos” árucikk fogalma. Végül hetedik és nyolcadik évfolyamon életszerū helyzetekben, konfliktushelyzetek felismerése és megoldási módok kitalálása okán várja el a kerettanterv egy-egy tagadó szerkezet megértését: például boltban vásárol, de nem elég a pénze az áru megvásárlására, akkor mit tegyen? Vagy a társas kapcsolatok területén magatartásszabályozási céllal kerül elő a „tudni, hogy mit tehet 
a tanuló mások előtt és mit nem" (például: diákszerelem megnyilvánulásai), illetve az „elfogadható és nem megengedhető tényezők elemzése egy kapcsolatban." Ugyanezeken az évfolyamokon a „beszédfejlesztés, anyanyelv” témakörben fejlesztési tevékenységként fogalmazódik meg, hogy a tanuló a cselekvést értékelő kérdésre állító, a valóságnak nem megfelelő kérdésekre tagadó mondatokat tudjon - immáron önállóan - szerkeszteni (kommunikáció kerettanterv 1-8. osztály, 2020; olvasás-írás kerettanterv 1-8. osztály, 2020).

Értelmezésünk szerint különösen hangsúlyossá a 7-8. osztályban válik a tagadás. Az értelmileg akadályozott tanulók 6-8 éves korukban válhatnak tankötelessé, illetve lehetősége van az iskolának arra, hogy például az első évfolyam anyagát ne egy, hanem két tanév alatt dolgozzák fel. Ezért a 7-8. osztályos tanulók 13-16 évesek lehetnek. Ezeken az osztályfokokon jelenik meg konkrétan először a beszédprodukció elvárásként: a tanuló általános módon maga is képessé kell, hogy váljon tagadást kifejező nyelvtani szerkezetek alkotására, azaz nem feltétlenül viselkedésszabályozási, viszonyulást vagy kívánságot kifejező céllal, hanem gyakorlati helyzetbe ágyazott módon.

\section{A TAGADÁSRA VONATKOZÓ SZABÁLYOK A KÖNNYEN ÉRTHETŐ ÜZENET KÉSZÍTÉSÉ- NEK SZABÁLYRENDSZERÉBEN}

Kutatásunk egyik céljaként jelöltük meg, hogy a könnyen érthetö üzenetek készítésének szabályrendszerére vonatkozóan javaslatokat teszünk. Ezért fontosnak tartjuk megvizsgálni, hogy vonatkoznak-e szabályok a tagadásra, és ha igen, akkor melyek ezek a szabályok. A tanulmány készítésekor Magyarországon az Inclusion Europe és az ÉFOÉSZ (2009) által kiadott szabályrendszert alkalmazzuk a könnyen érthető üzenetek készítésekor. A tagadásra vonatkozó szabály a szabályrendszerben nincsen.

Ugyanakkor az alkotók felhívják a figyelmet arra, hogy „Inkább pozitív tartalmú mondatokat használjunk, a negatív tartalmú helyett. Például ez egy pozitív tartalmú mondat: Itt kell maradnod addig, amíg a találkozó véget nem ér. Ez pedig egy negatív tartalmú mondat: A találkozó végéig nem mehetsz el" (Inclusion Europe \& ÉFOÉSZ, 2009:11). Benyomásunk szerint a szabályrendszer készítői nem a tagadó szerkezet megértésének a problémájából indultak ki, hanem egy pedagógiai elvböl: könnyebb azt megérteni, hogy mit tehetek, és ennek megfelelően cselekedni. Ha azt mondjuk meg például a gyermeknek az iskolában, hogy mit ne tegyen, akkor - még ha meg is érti annak a jelentését - azt nem hoztuk a tudomására, hogy mit tegyen. A fent idézett szabály ennek elkerülésére hívja fel a figyelmet.

Vegyük közben észre azt is, hogy miközben a tiltás helyett valóban megjelenik az elvárt viselkedés, tagadó szerkezet („...véget nem ér”) kerül a példamondatba. A példamondat összetett mondat (,,tt kell maradnod addig, amíg a találkozó véget nem ér."), aminek a megértése ugyancsak okozhat nehézséget. Úgy tünik tehát, hogy miközben a szabályrendszer alkotói elkerülik a tiltást, másféle nehézségek elé állítják az értelmileg akadályozott személynek üzenetet készítő szerzőket. Figyelemmel arra, hogy az Inclusion Europe és az ÉFOÉSZ (2009) szabályrendszere alapján 
kerülendő az összetett mondat, a tiltás, illetve ajánlott az üzenetet a lehető legkevesebb morfémával megfogalmazni (például „kell maradnod” helyett „maradj”), ezért megnéztük a magyar nyelvű szabályrendszer alapját képező eredeti angol nyelvű szabályrendszert is. "For example, say "You should stay until the end of the meeting" rather than "You should not leave before the end of the meeting" (Inclusion Europe, 2007:11)'. Ha minden, a fent bemutatott példa szempontjából releváns szabályt betartanánk, akkor az angol példamondatot az alábbi formában fordítanánk: „Maradj itt a találkozó végéig".

\section{A JELEN TANULMÁNY TEKINTETÉBEN MEG- VÁLASZOLANDÓ KUTATÁSI KÉRDÉSÜNK}

Mennyire sikeresen és hogyan értelmezik az értelmileg akadályozott általános iskolai tanulók a tagadó szerkezetű mondatokat? A kutatás eredményeiből milyen következtetéseket vonhatunk le a tagadó szerkezetek általános iskolai használata és a tagadó szerkezetet tartalmazó üzenet készítésére vonatkozó szabályok egyértelműsítése céljából?

A kommunikáció 1-8. osztály kerettanterv fent bemutatott elemzése alapján arra is kíváncsiak lehetünk, hogy a tagadás tervezett oktatása arra az életkorra, illetve elé vagy utána esik-e, amikor a tagadás biztos értelmezésének készsége a tanulóknál minden kétséget kizáróan megjelenik. Másképpen fogalmazva a kérdés az, hogy a kommunikáció 1-8. osztály kerettanterv készítői az értelmileg akadályozott gyermekek nyelvfejlődéséről szerzett tudományos ismereteknek megfelelően, céltudatosan tervezték-e meg a tagadás tanításának életkori sávját, vagy sajátélményű tapasztalataikra hagyatkozva helyezték el azokat az egyes osztályfokokon? Ha a tagadás kerettantervi tervezett tanításának ideje egybeesne a nevezett kompetencia tényleges birtoklásának életkori jellemzőjével, azzal igazolhatnánk vagy cáfolhatnánk azt a vélekedést, hogy az értelmileg akadályozott tanulók éppen annyira és akkor, többre vagy éppen kevesebbre képesek, mint amit a kerettantervek alapján adott életkori sávban elvárunk tőlük. A kutatási eredmények értelmezésével összefüggésben már itt meg kell azonban azt is jegyeznünk, hogy a nyelvfejlödés nem csak a tanuló érési folyamatától és a tudatos tanítástól függ, hanem például a gyermek nyelvi szocializációjától, kognitív képességeitől, intelligenciájától is.

\section{A KUTATÁS CÉLCSOPORTJA}

A kutatást értelmileg akadályozott tanulók általános iskolájában, 1-8. osztályban terveztük lebonyolítani. A COVID-19 vírushelyzetre figyelemmel személyes kapcsolati hálónkat mozgósítva választottunk ki olyan általános iskolákat, amelyek vezetése nyitott volt a kutatásban való részvételre. A mintába végül két budapesti, egy kecskeméti és egy kiskőrösi általános iskola került. Kizárólag azokat az 1-8. osztályba járó tanulókat vontuk be a mérésbe, akiknek a szakértői véleményében szerepelt a BNO F71-es kód. A kutatásból ugyanakkor kizártuk azokat az értelmileg akadályozott tanulókat, akik a BNO F71-es kód mellett autizmus diagnózissal is rendelkeztek. Az alapsokaságot - a négy iskolában - összesen 129 fö alkotta. Minden tanuló ese- 
tében küldtünk tájékoztató levelet és adatkezelési hozzájáruló nyilatkozatot a tanuló szülőjének vagy gyermekotthonban élő tanulók esetén a gyámnak. 77 tanuló szüleitől/gyámjaitól kaptunk írásos adatkezelési hozzájáruló nyilatkozatot. Ez az alapsokaság 60 százaléka. Az adatfelvételre 2020. szeptember 29-e és 2021. február 3-a között került sor.

\section{A KUTATÁs MÓdSZERE, ESZKÖZE}

Kutatásunk eszköze a standardizált TROG-H (Test for Reception of Grammar - Hungary) teszt, melynek célja a különböző nyelvtani szerkezetek megértésének felmérése 3-14 éves kor között.

Azért a TROG-H tesztet választottuk, mert Lukács és mtsai (2013:2) szerint a TROG-H tesztnek „az elméleti érdekességen kívül a gyakorlati jelentősége is nagy lehet, (...) a gyerekeknek szóló (például tankönyvi) nyelvezet kialakításában” is. Mint azt a Bevezetés című fejezetben kifejtettük, célunk ehhez nagyon hasonló: a kutatás eredményei alapján javaslatot szeretnénk megfogalmazni részben az értelmileg akadályozott tanulók nyelvi kompetenciája fejlesztésének módszertanára, részben a könnyen érthető üzenetek készítésének szabályaira vonatkozóan. Már itt jelezzük, hogy éppen ezért az eredmények bemutatásáról szóló fejezetben - figyelemmel jelen tanulmány keretében megválaszolható kutatási kérdésre - arra fókuszálunk, hogy mi jellemzi a tanulók teljesítményét a tagadó szerkezet értelmezését mérő itemekben, és nem vetjük majd össze a tanulók pontszámait a standard pontokkal.

Az eredeti tesztet angol nyelven Dorothy V. M. Bishop dolgozta ki (Bishop, 1983), majd a teszt magyar adaptációját Lukács Ágnes, Győri Miklós és Rózsa Sándor végezték (Lukács \& mtsai, 2011). A teszt alkalmazható a nyelvfejlődési zavart mutató gyermekek receptív nyelvi sajátosságainak felmérésére, továbbá a siketség, értelmi sérülés és a cerebrális parézis vizsgálatában, illetve felnőttkorban afázia esetén is. Az eljárás többszörös választáson alapuló egyéni vizsgálómódszer, ami összesen 18 blokkot tartalmaz, a blokkok pedig különböző nyelvtani szerkezetek megértését mérik (1. táblázat).

„Minden nyelvtani szerkezet megértésének vizsgálatához 4 olyan tétel (item) tartozik, amelyekhez egyenként 4 válaszlehetőség társul. Ennek alapján 0,4 százalék a valószínűsége annak, hogy a gyermek véletlenszerű mutogatással mind a 4 tételre helyesen válaszoljon" (Lukács \& mtsai, 2011:9). A vizsgált személynek itemenként rámutatással kell kiválasztania a négy kép közül azt, amelyikre a vizsgálatvezető által felolvasott mondat vonatkozik, azaz a vizsgált személytől nem igényel beszédet. A tesztmondatok korlátozott szókincsre épülnek. Ennek célja, hogy minimalizálja annak az esélyét, hogy a vizsgált személy azért ad hibás választ, mert nem érti a szavak jelentését (Lukács \& mtsai, 2011). A TROG-H tesztkönyvet és a kézikönyvet, valamint a vizsgálati ürlapokat az OS Hungary Kft.-től vásároltuk meg az Új Nemzeti Kiválóság Program (ÚNKP) keretében. 


\begin{tabular}{|c|c|}
\hline Blokk & Vizsgált nyelvtani szerkezet (példamondat) \\
\hline $\mathbf{A}$ & Főnév \\
\hline $\mathbf{B}$ & Ige \\
\hline C & Melléknév \\
\hline D & $\begin{array}{l}\text { Kételemű kombináció } \\
\text { (pl.: A macska szalad./A sárga motor.) }\end{array}$ \\
\hline $\mathbf{E}$ & $\begin{array}{l}\text { Tagadás } \\
\text { (pl.: A macska nem játszik.) }\end{array}$ \\
\hline $\mathbf{F}$ & $\begin{array}{l}\text { Háromelemű kombináció } \\
\text { (pl.: A macska megy a járdán.) }\end{array}$ \\
\hline G & $\begin{array}{l}\text { Egyes/többes számú személyes névmás } \\
\text { (pl.: A cica keresi őket.) }\end{array}$ \\
\hline H & $\begin{array}{l}\text { Felcserélhető szereplők } \\
\text { (pl.: A fiú nézi a cicát.) }\end{array}$ \\
\hline $\mathbf{J}$ & $\begin{array}{l}\text { Egyes/többes számú fönévrag } \\
\text { (pl.: A cica fellöki a cserepeket.) }\end{array}$ \\
\hline $\mathbf{K}$ & $\begin{array}{l}\text { Középfok/felsőfok } \\
\text { (pl.: A pohár magasabb, mint a kosár.) }\end{array}$ \\
\hline M & $\begin{array}{l}\text { Téri ragok (-ban és -on) } \\
\text { (pl.: A cica a vonaton van.) }\end{array}$ \\
\hline $\mathbf{N}$ & $\begin{array}{l}\text { Középre beágyazott mellékmondat, alany-alany } \\
\text { (pl.: A cica, ami a kosárban van, az fekete.) }\end{array}$ \\
\hline $\mathbf{0}$ & $\begin{array}{l}\text { X, de nem Y } \\
\text { (pl.: A kutya szalad, de az egér nem.) }\end{array}$ \\
\hline $\mathbf{P}$ & $\begin{array}{l}\text { Fölött és alatt } \\
\text { (pl.: A könyv a pohár alatt van.) }\end{array}$ \\
\hline $\mathbf{Q}$ & $\begin{array}{l}\text { Nemcsak } \mathrm{X} \text {, de } \mathrm{Y} \text { is } \\
\text { (pl.: A kosár nemcsak kicsi, de fekete is.) }\end{array}$ \\
\hline $\mathbf{R}$ & $\begin{array}{l}\text { Jobbra beágyazott mellékmondat, alany-X } \\
\text { (pl.: A madár azt a magot eszi, ami fekete.) }\end{array}$ \\
\hline $\mathbf{s}$ & $\begin{array}{l}\text { Sem X, sem } Y \\
\text { (pl.: A kosár se nem kicsi, se nem barna.) }\end{array}$ \\
\hline $\mathbf{T}$ & $\begin{array}{l}\text { Középre beágyazott mellékmondat, X-alany } \\
\text { (pl.: A ló, amit a fiú etet, az nagy.) }\end{array}$ \\
\hline
\end{tabular}

1. táblázat. A TROG-H teszttel vizsgált nyelvtani szerkezetek a szerzők példamondataival, közzététel a Giunti Psychometrics Hungary Kft. engedélyével

\section{A KUTATÁSI EREDMÉNYEK BEMUTATÁSA ÉS ÉRTELMEZÉSE}

Ahogyan arra korábban már utaltunk, ebben a tanulmányban kizárólag azokat a blokkokat elemezzük, amely blokk nyelvi szerkezetében megjelenik a tagadás valamilyen formában. Tagadó szerkezetű mondat megértését vizsgálja az E blokk (tagadás), az $O$ blokk ( $X$, de nem $Y$ ) és a $Q$ blokk (nemcsak $X$, de $Y$ is), valamint az $S$ blokk (sem $\mathrm{x}$, sem $\mathrm{Y})$.

A kommunikáció és az olvasás-írás 1-8. osztály kerettantervek fentiekben bemutatott fókuszált elemzésével úgy véljük, hogy nem kerültünk közelebb a célunkhoz. Valójában a tagadás feltárt kerettantervi előfordulásai nem feleltethetők meg 
egyértelműen a TROG-H tesztben elvárt blokkok (azon belül itemek) szerkezeteinek. Ez alól kivételt az E blokk (tagadás) jelent. A további tagadást kifejező $(\mathrm{O}, \mathrm{Q}$ és S) blokkoknak megfelelő nyelvi szerkezetek a kerettantervekben egyértelműen azonosítható módon nem jelennek meg. És itt megint hangsúlyozzuk azt is: arról, hogy a gyógypedagógusok mikor, mit és milyen módon valósítanak meg a kerettantervi szabályozásból, nincs empirikus kutatáson alapuló tudásunk. Ezt a szálat ezért egyelöre el kell engednünk.

Az eredmények értelmezéséhez elengedhetetlen információ, hogy a TROG-H tesztfelvételt a tesztkönyvben (Lukács \& mtsai, 2011) rögzített tesztfelvételi szabályok szerint végeztük. Így nem minden tanulóval vettük fel mind a 18 blokkot, hanem a teljesítményük alapján különbözö blokkoknál állítottuk le a tesztfelvételt. Egy blokknak tekintünk egy 4 itemböl álló sorozatot, amely ugyanannak a szerkezetnek a megértését vizsgálja. A tesztfelvételi szabályok alapján az a tanuló teljesítette az adott blokkot, aki a blokkban szereplő 4 itemből mindegyikre helyes megoldást adott. Amikor egy adott blokkban akár csak egy item esetén nem jó a megoldás, akkor az adott blokkot nem teljesítettnek kell tekinteni. Ha egy tanuló egymást követő 5 blokkot ebben az értelemben nem teljesít, akkor a tesztfelvételt abbahagyjuk, és a további blokkokat ezzel a tanulóval már nem vesszük fel. Abban az esetben is abbahagyjuk a tesztfelvételt, ha a tanuló 8 egymást követő itemre nem ad választ, azaz egy képre se mutat rá a vizsgálatvezető felszólítása ellenére (Lukács \& mtsai, 2011). Kutatásunk során az „A” és a „B” blokkot minden tanulóval felvettük (77 fö), majd a tesztfelvételt a leírtaknak megfelelően szakítottuk meg. A következő diagramban bemutatjuk, hogy az egyes blokkokat hány tanulóval vettük fel.

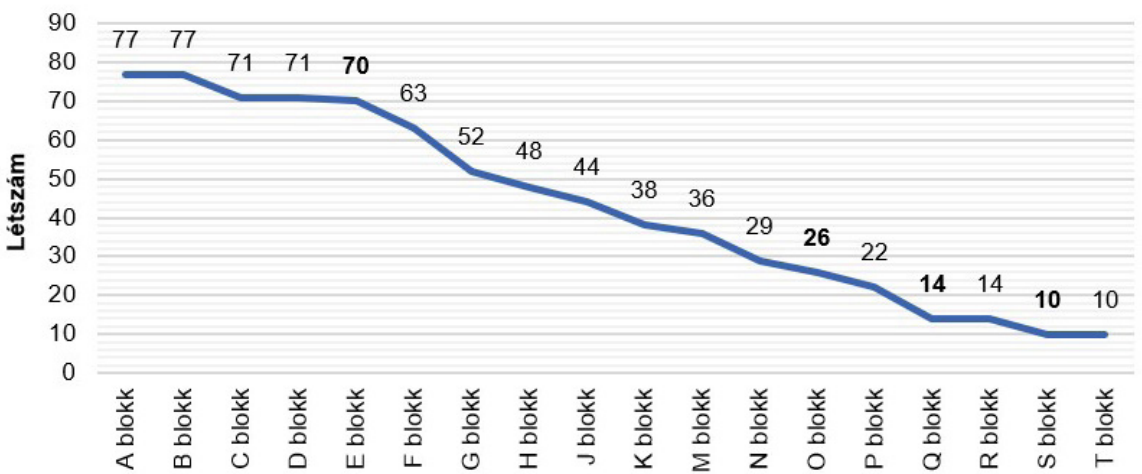

1. diagram. Az adott blokkot teljesítő tanulók száma

Az 1. diagramon megfigyelhetjük, hogy a tagadást kifejező $E$ blokkig 70 , az $O$ blokkig már csak 26, a Q blokkig 14, a S blokkig pedig 10 tanuló jutott el, amelyböl arra is következtethetünk, hogy az egyre bonyolultabb nyelvtani szerkezetek (lásd: 1. táblázat) pontos értelmezése egyre nagyobb kihívást jelent a tanulóknak.

Az eredmények értelmezése elött adattisztítást végeztünk. A kutatásban részt vevő 77 tanulóból 7 tanuló nem jutott el az „E” (tagadás) blokknak a kitöltéséig. Mivel az „E” az ötödik blokk, ez csak abban az esetben volt lehetséges, amikor a tanuló nyolc egymást követő item esetén nem adott választ. A hétből hat tanuló egyszer 
sem mutatott rá az első négy blokkban egy képre sem; egy tanuló pedig csupán egy esetben mutatott rá egy képre. Ők tehát nem voltak bevonhatók a tesztfelvételi helyzetbe, aminek csak az egyik lehetséges oka a beszédértés elmaradása. A tölük kapott eredményeket ezért ebben a tanulmányban nem elemezzük. Így a tagadást tartalmazó blokkokat elemző fejezetekben 70 tanuló eredményeit mutatjuk be (ez a kutatásba bevont tanulók 91 százaléka).

A 70 tanuló életkori összetételét a 2. diagramban ábrázoljuk.

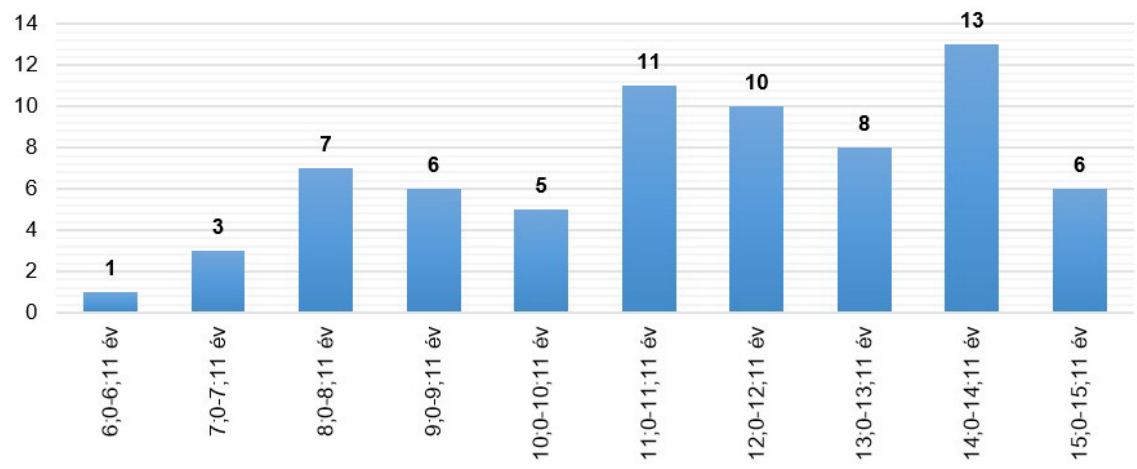

2. diagram. Az elemzésbe bevont tanulók életkori eloszlása

A 2. diagram alapján látható, hogy a különböző életkori övezetekböl bevont tanulói létszám nagyon különböző (1-13 fö). Ezért az életkori adatok alapján történő elemzés csak nagyobb minta alapján, egy későbbi kutatás keretében lesz elvégezhető.

\section{Tagadás (E blokk) eredményeinek bemutatása és értelmezése}

Az E blokkot teljesítő 70 tanuló eredményét három kategóriába soroltuk: (1) érti az adott nyelvtani szerkezetet; (2) kialakulóban van a nyelvtani szerkezet megértése; vagy (3) nem érti a nyelvtani szerkezetet. Azok a tanulók, akik 4/4 helyes választ adtak az adott blokkban, értik az adott nyelvtani szerkezetet. Akiknél kialakulóban van az adott nyelvtani szerkezet megértése, azok blokkonként változó számú - egy, kettő vagy legfeljebb három - hibát ejtettek. Ez azt jelenti, hogy „a gyermek már rendelkezik valamilyen ismerettel a vizsgált nyelvtani szerkezettel kapcsolatban, de ez a tudás még nem kialakult, a teljesítménye ingadozik" (Lukács \& mtsai, 2011:36). Azokról a tanulókról mondható el, hogy nem értik az adott nyelvi szerkezetet, akik mind a négy esetben rossz választ adtak, azaz rossz képre mutattak vagy nem mutattak rá egy tesztképre sem az egyes itemek esetén (Lukács \& mtsai, 2011). Az O, a $Q$ és az $S$ blokkok esetében a következő fejezetben is azonos módon mutatjuk be a kapott adatokat.

Az egyszerű tagadó szerkezet értését mérő „E” blokkot 25 fő (36 százalék) érti, azaz ök adtak mind a 4 tesztmondatra helyes választ. Kialakulóban van a nyelvtani szerkezet megértése 36 fö (51 százalék) esetében. 9 tanuló (13 százalék) nem adott 


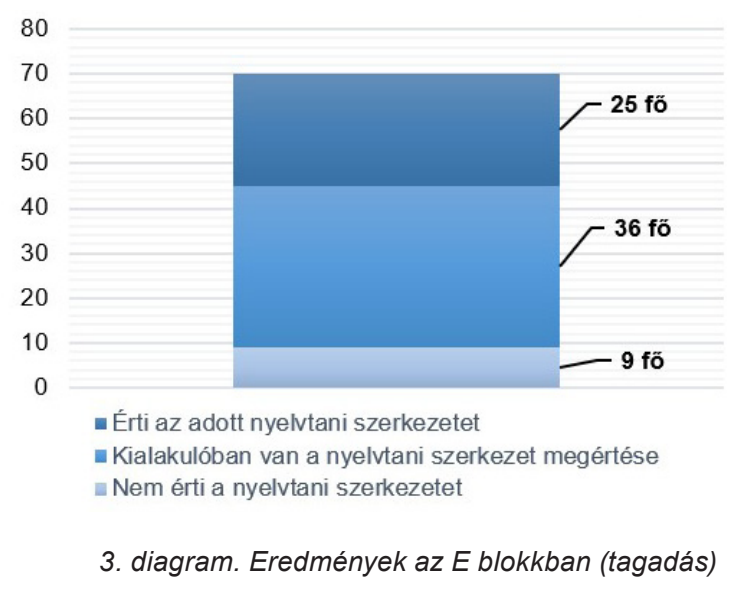

jó választ, azaz nem értik a tagadó nyelvi szerkezetet (3. diagram). Ezek az eredmények azt jelzik, hogy még az egyszerü tagadó szerkezet tudatos tanítása is fontos feladata kell legyen a gyógypedagógusnak.

A TROG-H teszt E blokkjának felvétele során nyert adatok lehetővé teszik, hogy itemenként is megvizsgáljuk, a tanulók hány esetben vétettek lexikális hibát, és hány esetben grammatikait. A továbbiakban bemutatásra kerülő grammatikai/lexikai hibák könnyebb értelmezhetösége érdekében most bemutatjuk a 17. tesztmondathoz tartozó képet (1. sz. kép).

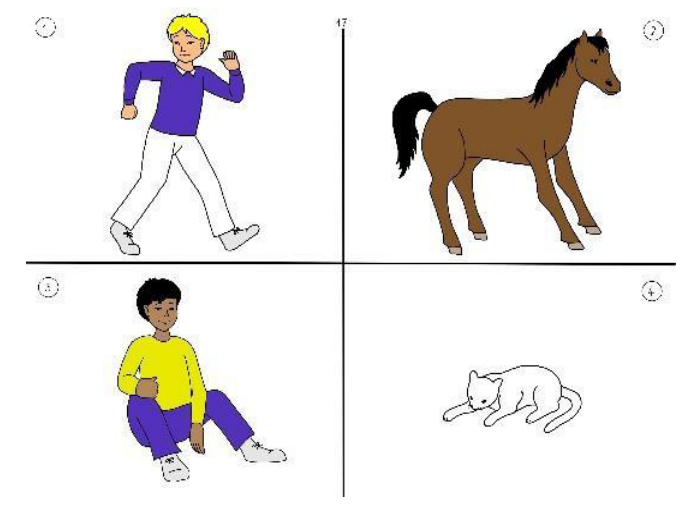

1. sz. kép. TROG-H tesztkönyv 17. képsor („A fiú nem fut.”).

A kép nem azonos a tesztkönyvben szereplő képpel. Az itt közzétett képet rajzolta: Aigner Petra. Közzététel: a Giunti Psychometrics Hungary Kft. engedélyével.

Ennél az itemnél a 3-as kép a helyes megoldás (A fiú nem fut.). Az 1-es kép a grammatikai elterelő (A fiú fut, és nem ül.) A 2-es és a 4-es képek lexikai elterelők (nem fiút látunk a képen, hanem lovat, illetve cicát).

Az alábbi diagramon az $\mathrm{E}$ blokk mind a 4 itemje esetében láthatóvá tesszük a grammatikai, illetve a lexikális hibát vétők arányát. 


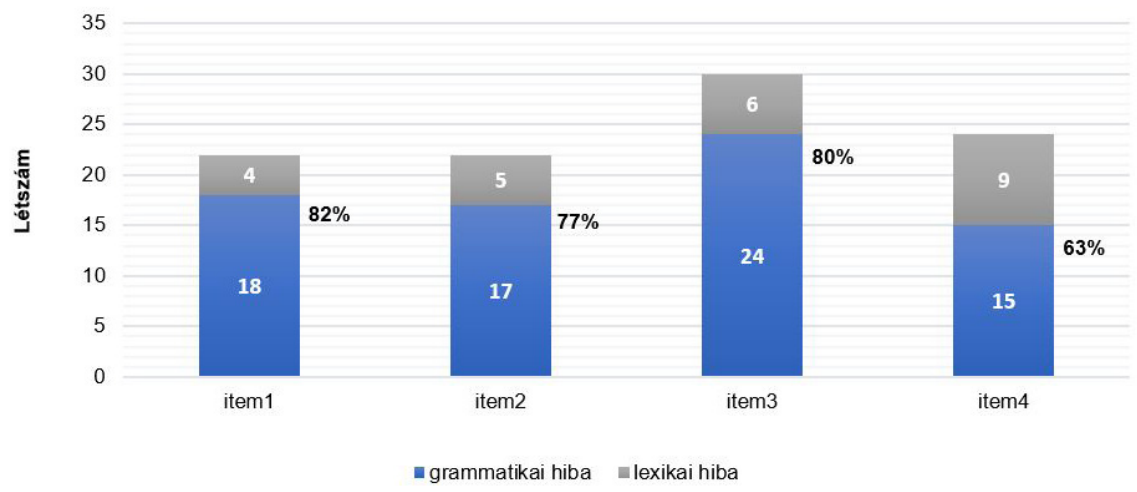

4. diagram. A grammatikai és a lexikai hibák aránya

A 4. diagramon látható, hogy az $E$ blokk minden iteme esetében jelentősen nagyobb arányban (82, 77, 80 és 63 százalékban) grammatikai hiba okozta a rossz választ, ami arra utal, hogy a mondatban szereplő szavak jelentését a tesztalanyok megértették. A nehézséget tehát a tagadás értelmezése okozta.

\section{Az O blokk (X, de nem Y), Q blokk (nemcsak X, de $Y$ is) és az $S$ blokk (sem $X$, sem $Y$ ) eredményeinek bemutatása}

Az O blokk kitöltéséig a 70 föből 26 fő (37 százalék), az Q blokkig 14 fő (20 százalék), az S blokkig pedig 10 fö (14 százalék) jutott el.

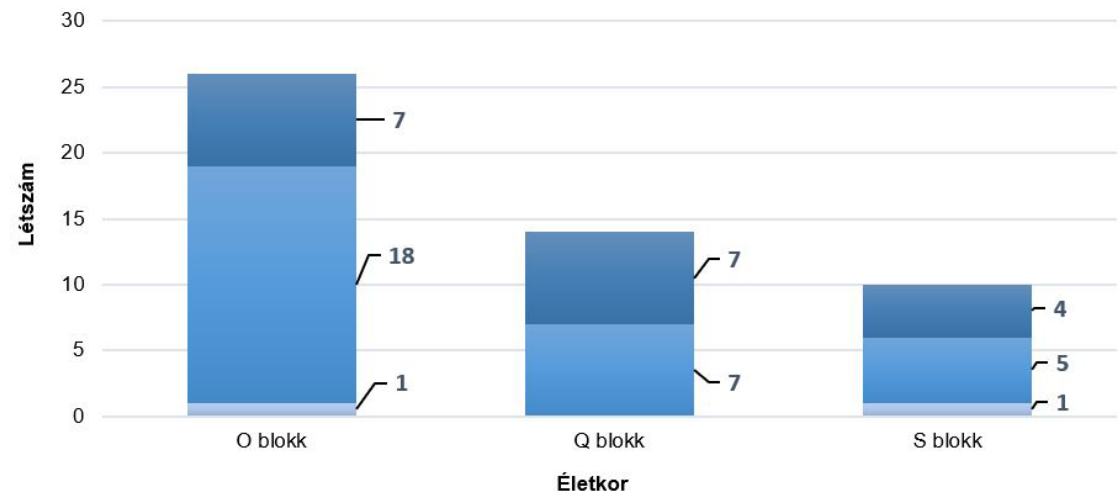

-Nem érti a nyelvtani szerkezetet

- Kialakulóban van a nyelvtani szerkezet megértése

-Érti az adott nyelvtani szerkezetet

5. diagram. Eredmények az $O$, a $Q$ és az S blokkban 
Az 5. diagramról leolvasható, hogy a „X, de nem Y” szerkezetű mondatokat (O blokk) hét fő érti, további 18 tanulónál kialakulóban van a nyelvtani szerkezet megértése, és egy tanuló nem érti ezt a nyelvtani szerkezetet. $A$ "nemcsak $X$, de $Y$ is” ( $Q$ blokk) szerkezetű mondatokat hét fő érti, hét tanulónál kialakulóban van a nyelvtani szerkezet megértése, és azon tanulók között, akik eljutottak idáig a tesztfelvételben, nincs olyan, aki nem érti ezt a szerkezetet. A „sem x, sem Y” (S blokk) szerkezetű mondatokat négy fö érti, további öt tanulónál kialakulóban van a nyelvtani szerkezet megértése, egy tanuló pedig nem érti ezt a nyelvtani szerkezetet.

$\mathrm{Az} \mathrm{O}, \mathrm{a} \mathrm{Q}$ és az S blokkban nincs lexikai elterelő, így minden tévesztés grammatikai tévesztésnek minősül.

Végezetül közöljük az adott blokkot teljesítő, illetve az adott nyelvtani szerkezetet értő tanulók számát.

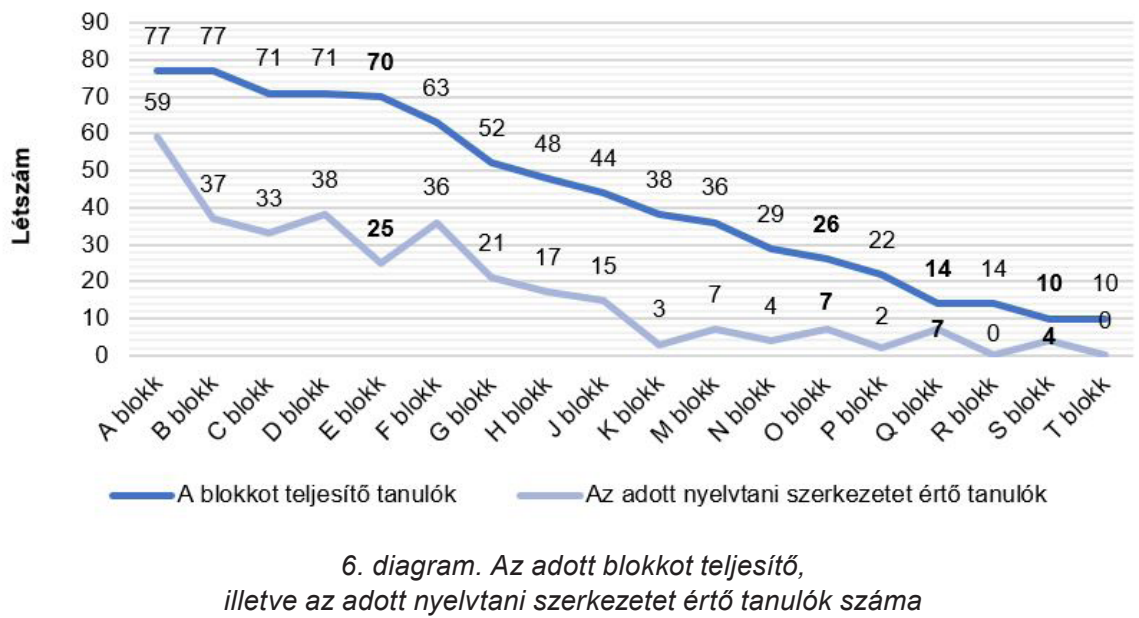

\section{ÖSSZEFOGLALÁS}

Az előző fejezetben bemutatott adatok igazolni látszanak azt, hogy a tagadó szerkezetű mondatok értelmezése valóban nehézséget okoz az értelmileg akadályozott tanulóknak. Bár az egyszerű mondatban megjelenő tagadást ( $E$ blokk) a tanulók 36 százaléka (25 fö) érti, az összetett mondatban megjelenő, bonyolultabb szerkezetű O és $Q$ blokk szerinti nyelvtani szerkezetet már csak a tanulók 10 százaléka (7 fö), a $S$ blokkot pedig csak 6 százaléka (4 fö) érti.

Biztatónak látjuk ugyanakkor azt, hogy az E blokkot teljesítő 70 tanuló 51 százaléka (36 fő), az O blokkot teljesítő 26 tanuló 69 százaléka (18 fö), a Q blokkot teljesítő 14 tanuló 50 százaléka (7 fö), az S blokkot teljesítő 10 tanuló 50 százaléka (5 fő) esetében az adott, tagadást kifejező szerkezet megértése kialakulóban van (lásd 3. 5. és 6. diagram).

Szeretnénk megjegyezni, hogy kutatásunk nem tekinthető reprezentatív kutatásnak. Így eredményeink sem általánosíthatók. Ugyanakkor a kutatási tapasztalataink meggyőznek arról, hogy a TROG-H teszttel történő adatgyűjtést érdemes nagyobb, akár országos mintán is elvégezni. 
A kutatási eredmények értelmezésének korlátjaként tekintünk továbbá néhány további kutatási tapasztalatra. Bár ahogyan azt fent jeleztük, a tesztfelvétel során betartottuk a kézikönyv szerinti eljárásrendet, megfigyeltük, hogy a tanulók megoldását néhány dolog befolyásolhatta. A tesztmondat értelmezését az adatfelvevő például a mondaton belüli hangsúlyok módosításával, illetve a hanglejtéssel segítheti vagy éppen akadályozhatja is. Talán nem mindegy, hogy például a „Fiú nem fut.” mondatban a nem szót hogyan ejtjük: hangsúlyosan vagy nyomaték nélkül. A tesztkönyv erre is ad iránymutatást: a tesztmondatokat tisztán és természetesen kell felolvasni, a kritikus (vizsgált) morfémának enyhe, de nem természetellenes hangsúlyt adva (Lukács \& mtsai, 2011). A vizsgálati helyzetben ezt a szempontot nem könnyű mindvégig megtartani, feltehetöleg ezt egy hanganyag lejátszása tudná csak egységesen biztosítani. Másfelöl a tanulói megoldást befolyásolhatja az is, hogy a tesztmondatot a tesztkönyvben történő lapozás közben (túl gyorsan) vagy a tesztoldal megtekintésére biztosított néhány másodpercet követően (a képi információ feldolgozására kellő időt engedve) mondjuk el; ehhez szintén biztosít támpontot a kézikönyv.

Az értelmileg akadályozott tanulókról tudjuk, hogy a figyelmüket a szokásosnál rövidebb ideig lehet fenntartani. A jelen elemzésben bemutatott $O$ blokkig például 12 blokkot kellett már teljesíteni, azaz 48 mondathoz tartozó képre kellett rámutatni. Így a tévesztések nemcsak a szókincs hiányával és/vagy a grammatikai szerkezet értelmezése körüli nehézségekkel, hanem akár a figyelem kifáradásával is magyarázhatók. Jó példa lehet erre az az eset, amikor a tanuló több egymást követő feladat megoldásakor, a tesztmondatot szinte ki sem várva, a 4 kép közül konzekvensen a mutatáshoz használt kezéhez legközelebb eső, jobb alsó képre mutatott.

A jelen tanulmányban vizsgált tesztmondatoknak a terjedelme is változik. $\mathrm{Az} E$ blokkhoz képest az $\mathrm{O}, \mathrm{Q}$ és $\mathrm{S}$ blokkokban a tesztmondatok egyre több szóból állnak. Így a tévesztést a tesztmondat megjegyzéséhez szükséges munkamemória terjedelme is befolyásolhatja.

\section{KÖVETKEZTETÉSEK ÉS JAVASLATOK}

A kutatási eredmények értelmezésének korlátaira figyelemmel kísérletet teszünk néhány, a kutatási eredmények alapján mégis hasznosnak tűnő tanács megfogalmazására.

1. Javasoljuk az általános iskola legalább alsó tagozatán a tagadást kifejező mondatok használatának kerülését úgy szóban, mint képi vagy írott nyelvi formában, azokban az esetekben, amikor nem kifejezetten a tagadás tanítása a cél. Ha lehetséges, akkor ezek helyett állító mondatokat fogalmazzunk meg.

2. Szükségesnek tünik a tagadószavak és tagadó szerkezetek jelentésének, jelentést módosító hatásának tudatos tanítása, különösen a felső tagozaton. Érdemes a tagadást kifejező egyszerű mondatok felől a tagadást kifejező öszszetett mondatok felé haladni.

a) A tagadó szerkezet megértését a szokásosnál erőteljesebb hangsúlyozással és hanglejtéssel támogassuk. A közléshez további kiegészítő magyarázatot is füzhetünk. Ha van rá lehetőség, akkor szemléltessük is a gondolatunkat. 
b) Feltételezhetjük, hogy amíg az értelmileg akadályozott tanuló a konkrétan felismerhető fogalmakat, cselekvéseket (például kutya, kislány, fiú, illetve ül, ugrik, iszik, fut) könnyebben felismeri, addig a konkrétan nem látható cselekvések (például nem ül, nem ugrik, nem iszik, nem fut - hanem valami mást csinál) megértése bizonytalanabb. Tanítás során a láthatatlan „nem” szó értelmezését nonverbális jelekkel mégis láthatóvá tudjuk tenni. Miközben mondjuk (nyelvi jel) például „A kutya nem ül.” mondatot, a „nem” szó hangoztatása közben fejrázással, és/vagy az ökölbe zárt kézzel, de felfelé mutató mutatóujjunkat jobbra-balra mozgatva (nem szóbeli jel) tudatosan megerősíthetjük a tagadószó jelentését.

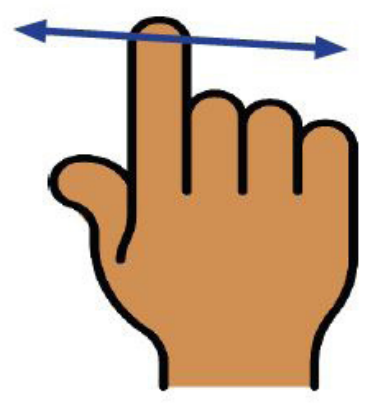

2. sz. kép. A „nem” szó jelentésének megerősitése nonverbális jellel

A kommunikáció 1-8. osztályos kerettantervben az 1-2. osztályos tananyagban, a társadalmi érintkezési formák témán belül, megfigyelhetünk ezzel kapcsolatos példát, amikor a fejlesztési tevékenységek között szerepel a fejrázás mint kommunikációs eszköz. Javasolt lehet azonban további hasonló fejlesztési tevékenységek és fejlesztési célok kidolgozása és beiktatása a kerettantervbe.

\section{Javaslatok az értelmileg akadályozott személyeknek szóló könnyen érthető üzenet készítésének szabály- rendszeréhez}

1. Tiltást kifejező gondolatok helyett inkább arról írjunk, hogy mit kell az olvasónak tennie. Ha mégis alkalmazzuk a tiltást, akkor tegyük mellé azt is, hogy milyen magatartást, cselekvést várunk el a tiltott magatartás, cselekvés helyett. Például „A piros lámpánál ne menj át a zebrán!” helyett „Piros lámpánál állj meg! Várd meg a zöld lámpát! Zöld lámpánál menj át a zebrán!”

2. Lehetőség szerint ne használjunk tagadó szerkezetű, egyszerü mondatokat a könnyen érthető szövegben. Az összetett mondatokban a kifejezett tagadást mindenképpen kerüljük el (például nemcsak..., de...; sem..., sem...). A tagadó szerkezet helyett állításokat fogalmazzunk meg. Ha mégis írunk tagadó szerkezetet, akkor a szöveget képi formában is magyarázzuk meg. Az összetett mondatot bontsuk egyszerủ mondatokra.

Kutatási tapasztalataink alapján fontosnak tartjuk azt is, hogy ne csak az értelmileg akadályozott tanuló felméréskori státuszát (a vizsgálati protokoll betartása 
melletti, beavatkozásmentes aktuális teljesítményét) tudjuk feltárni. Az adatfelvételkor számos olyan pillanatnak voltunk a részesei, amikor úgy éreztük, „egy pici” segítséggel a tanuló másodszorra meg tudta volna oldani a feladatot. Ugyanakkor az ilyen „pici segítségnyújtásra” a tesztfelvételi eljárás nem adott lehetőséget. Akadályt jelenthet továbbá az is, hogy az adott tesztfelvételi protokoll nincs tekintettel az értelmileg akadályozott tanulók figyelmének, munkamemóriájának a jellemzőire. Nincs mód arra sem, hogy a szóbeli közlés helyett például képi úton adjunk utasítást. Meggyőződésünk, hogy a gyógypedagógus gyakorlati munkáját olyan, az értelmileg akadályozott tanuló jellemzőit figyelembe vevő pedagógiai diagnosztikai eszközzel lehetne jól támogatni, amelynek alkalmazásával az értelmileg akadályozott tanuló tanulási folyamatának jellemzőit is fel tudjuk tárni. Ezért egy olyan új, kifejezetten értelmileg akadályozott tanulók felmérését szolgáló kutatási eszköz megalkotásán gondolkodunk, amellyel azt is láthatóvá lehetne tenni, hogy például milyen típusú nonverbális jelekkel lehet elősegíteni a megértést, ezzel a sikerélményt. Az értelmileg akadályozott, 1-8. osztályos tanulók fejlesztésének, tanításának és nevelésének egyes szakaszaiban ezek a többletinformációk talán több gyakorlati ismerethez vezethetnének.

Bízunk abban, hogy ezzel a kutatási beszámolóval hozzájárulhatunk az értelmileg akadályozott tanulók beszédértésének jobb megismeréséhez, illetve a könnyen érthető kommunikációban adekvát és tudományosan bizonyított szabályok kidolgozásához.

\section{KöSZÖNETNYILVÁNÍTÁS}

Szeretnénk köszönetet mondani azoknak az intézményvezetőknek, akik lehetőséget biztosítottak arra, hogy az általuk vezetett intézményekben végezzük az adatfelvételt. Köszönetet mondunk továbbá az egyes intézményekben a kapcsolattartó személyeknek és az osztályfőnököknek, akik az adatfelvételhez szükséges előkészületekben, az adatfelvétel menetének koordinálásában és lebonyolításában nélkülözhetetlen segítséget nyújtottak. Hálásak vagyunk a szülöknek és a tanulóknak az adatfelvételhez való hozzájárulásért és az együttműködésért. Végül köszönjük az anonimizált adatok rögzítéséhez és az elemzéshez nyújtott segítséget a statisztikusnak.

\section{Irodalom}

Babarczy A., Lukács Á. \& Pléh Cs. (2015). 10. A nyelvelsajátítás elméleti modelljei. In Pléh Cs. \& Lukács Á. (szerk.) (2015). Pszicholingvisztika. Akadémiai Kiadó. Budapest.

Bishop, D. V. M. (1983): Test for the Reception of Grammar. OS Hungary, Budapest.

Csákvári, J. (szerk.) (2006). Ajánlások értelmileg akadályozott gyermekek, tanulók kompetencia alapú fejlesztéséhez: Szociális, életviteli és környezeti kompetenciák. suliNova Kht., Budapest.

Hegedüs H. (2020). A kevesebb néha több. Fogyatékosság és Társadalom 2020.1:63-73. https://doi.org/10.31287/FT.hu.2020.1.7

Horváth P. L. (2020c). A könnyen érthetö kommunikációs képzési programok képzésfejlesztésének története Magyarországon a fogyatékossággal élő személyek jogairól szóló ENSZ egyezmény tükrében. (Doktori értekezés.) Eszterházy Károly Egyetem, Eger.

Horváth P. L. (2020a). Mit jut eszébe erröl a szóról: fogyatékosság? Carissimi, 11.1:13-15.

Horváth P. L. (2020b). Mi jut eszébe erről a szóról: fogyatékosság? II. Carissimi, 11.2:9-10. 
Inclusion Europe \& ÉFOÉSZ (2009). Információt mindenkinek! A könnyen érthető kommunikáció európai alapelvei. Inclusion Europe - ÉFOÉSZ, Brüsszel - Budapest.

Irányelvek a sajátos nevelési igényű tanulók iskolai oktatásához (2020). https://www.oktatas.hu/ pub bin/dload/kozoktatas/kerettanterv/SNI iranyelvek.docx Letöltés ideje: 2020.12.21.

Keszler B. \& Lengyel K. (2019). Kis magyar grammatika. Akadémiai Kiadó. Budapest. https://doi. org/10.1556/9789630599641

Kocsisné Kálló V., Túriné Gál A. \& Ruzsics I. (2013). Kommunikáció fejlődése és fejlesztése értelmileg akadályozott személyeknél. http://www.jgypk.hu/mentorhalo/tananyag/Kommunikci_fejldse_s_fejlesztse_rtelmileg_akadlyozott_szemlyeknl/index.html Letöltés ideje: $2020.12 .2 \overline{2}$.

Kommunikáció - kerettanterv a középsúlyos értelmi fogyatékos tanulók számára 1-8. évfolyam. 2020 https://www.oktatas.hu/pub_bin/dload/kozoktatas/kerettanterv/ksni_1_8/Kommunikacio.doc Letöltés ideje: 2020.12.22.

Lukács Á. \& Kas B. (2014). Nyelvelsajátítás és értelmi fogyatékosság. In Pléh Cs. \& Lukács Á. (szerk.), Pszicholingvisztika 2. Akadémiai Kiadó, Budapest. 1383-1403.

Lukács Á., Győri M. \& Rózsa S. (2011). TROG Kézikönyv. OS Hungary, Budapest.

Lukács Á., Győri M. \& Rózsa S. (2013). TROG-H: új sztenderdizált módszer a nyelvtani megértés fejlődésének vizsgálatára. Gyógypedagógiai Szemle, 41.1:1-22.

Lukács Á., Pléh Cs. \& Racsmány M. (2008). Szabályos és kivételes morfológia Williams-szindrómában. In Gervain J. \& Pléh Cs. (szerk.), A láthatatlan nyelv. Gondolat, Budapest.

Olvasás-írás kerettanterv a középsúlyosan értelmi fogyatékos tanulók számára 1-8. évfolyam (2020). https://www.oktatas.hu/pub_bin/dload/kozoktatas/kerettanterv/ksni_1_8/Olvasas-iras.doc Letöltés ideje: 2020.12.20.

Radványi K. - Pléh Cs. (2002): Középsúlyos értelmi fogyatékos, iskoláskorú gyermekek beszédének néhány nyelvtani jellemzője. Pszichológia, 22.3:245-254.

Radványi K. (2005). Kromoszóma-rendellenesség miatt fejlődési elmaradást mutató Down-szindrómás személyek nyelvi képességeinek vizsgálata. In Gervain J., Kovács K., Lukács Á. \& Racsmány M.: Az ezerarcú elme. Tanulmányok Pléh Csaba 60. születésnapjára. Akadémiai Kiadó, Budapest. 88-101.

Sápiné Bényei R. (2020). Magyar nyelv 5. NAT2020. Oktatási Hivatal, Budapest. https://www. nkp.hu/tankonyv/magyar_nyelv_5_nat2020/Letöltés ideje: 2021.03.01.

Az értelmileg akadályozott tanulók általános iskolai oktatását a kerettantervekben szereplő fogalmak könnyen érthető képi magyarázatával támogatjuk. Az alsó tagozatos kerettantervek alapján eddig 550 db kép készült el. A képek megrajzolásakor törekedtünk a személyállandóságra. A KÉK Család tagjai az összes, személyeket ábrázoló képen visszaköszönnek.

Partnereink a fejlesztésben: Csalogány EGYMI, Budapest és Kozmutza Flóra EGYMI, Hódmezőváráshely, valamint az SZTE JGYPK gyógypedagógia alapképzési szak hallgatói. További információkért kövesse a projekt facebook oldalát, vagy olvassa el a képtár bemutatásáról szóló híreket.

\section{A KÉK Család tagjai}

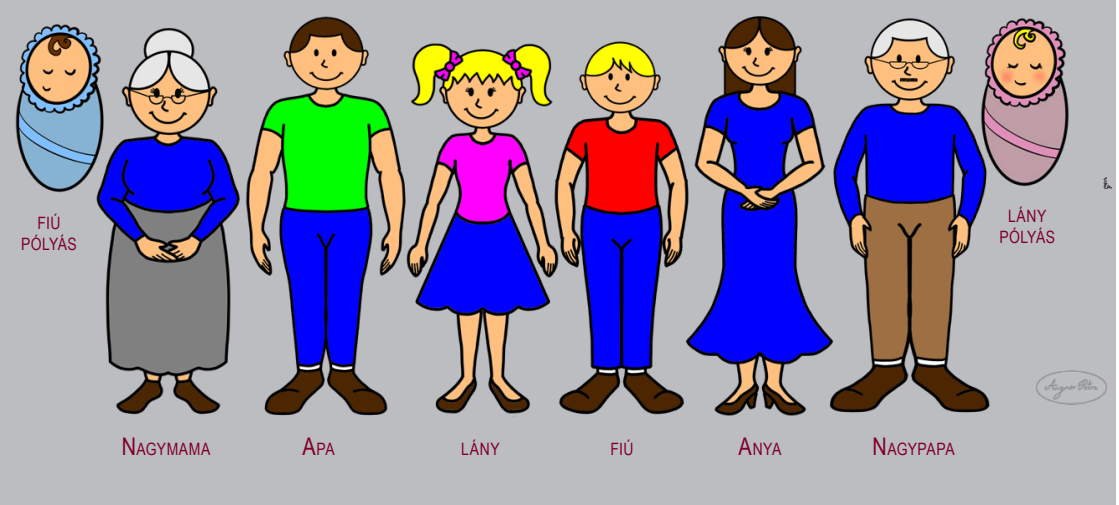

